\title{
IMPROVING STUDENTS' READING COMPREHENSION USING WORD-TO-PARAGRAPH ANALYSIS (A Case Study on The Reading Ability of The English Department Students of Tarbiyah Faculty of Alaudin State Islamic University)
}

\section{Bahrani}

\begin{abstract}
Fokus riset ini adalah penggunaan kata dalam analisa paragraf terhadap bacaan para mahasiswa dalam memahami bacaan. Maka permasalahan dalam penelitiun ini adalah sebagai berikut: (1) Apakab penggunaan analisa kata mampu memperbaiki pemahaman baiaan siswa? (2) Apakab penggunaan analisa frase/ungkapan mampu memperbaiki pemabaman bacaan siswa? (3) Apakah penggunaan analisa kalimat mampu memperbaiki pemahaman bacaan siswa? (4) Apakah penggunaan analisa paragraf mampu memperbaiki pemahaman bacaan siswa? Berdasarkan pembahasan di atas, peneliti menyimpulkan babwa penggunaan kata, kalimat, dan analisa paragraf mampu meningkatkan pemahaman bacaan siswa, tetapi analisa frase tidak dapat meningkatkan kemampuan pemahaman siswa dalam membaca.
\end{abstract}

Keywords: analisa paragraf, pemahaman bacaan, frase

\section{A. Introduction}

Reading is one of the most important skills in learning a language besides listening, speaking and writing. The fundamental goal of any reading activity is to know enough scientific concepts and knowing the language. In Indonesia, students treat this as a bridge to understand scientific books written in English. As they lack

Drs Bahrani MPd adalah Dosen dan Ketua Program Studi Bahasa knowledge of English, they often encounter difficulties when reading 
their compulsory books written in that language.

Scientific and technical texts contain a great deal of information, most of which consists of facts. Readers of such texts must be able not only to extract information but also to understand the material fully. Hence careful and thorough reading is required. William (1991) states that the effective reader brings with him the ability to recognize the purpose of the text as a whole, to see how the text is recognized and to understand the relationship between sentences

Comprehension (Anonymous, 1997) is the understanding and interpretation of what is read. To be able to accurately understand written material, students need to be able to: (1) decode what they read, (2) make connections between what they read and what they already know, and (3) think deeply about what they have read. One big part of comprehension is having a sufficient vocabulary, or knowing the meanings of enough words.

Readers who have strong comprehension are able to draw conclusions about what they read - what is important, what is a fact, what caused an event to happen, which characters are funny. Thus comprehension involves combining reading with thinking and reasoning.

To determine how children best learn to comprehend what they read, there are three areas regarded as essential to developing reading comprehension, namely: vocabulary development, text comprehension instruction, and teacher preparation and comprehension strategies instruction. For literal teading comprehension, this involves acquiring information that is directly stated in a selection. Recognizing stated main ideas, details, causes and effects, and sequences is the basis of literal comprehension, and through understanding of vocabulary, sentence meaning, and paragraph meaning is important.

Reading comprehensively is a problem for those whose native language is not English, however students have to read English texts and journals, since most scientific and technical knowledge is recorded in this language (Wiriyachitra and Chanya, 1989). The problem can be alleviated through the strategy of method used by teacher in the classroom that will enable the students to cope with English text on various subjects as stated by William (1991) that part of the teacher's job is therefore to develop within the learner strategies that will help him in this second, activities that will focus the students' attention on the text. The students must develop his own skills, but the teacher 
must make them aware what they are doing, and interested in doing it better (Nuttal, 1982).

Royer (2000) says that reading comprehension is the process of understanding and constructing meaning from a piece of text. Connected text is any written material involving multiple words that forms coherent thoughts. Phrases, sentences, paragraph and so on are examples of connected text that can be read with comprehension. Reading difficulties become most apparent when the reader is unable to grasp the meaning from a text passage. Reading comprehension may be affected by the difficulty of the text, the vocabulary words used in the text, and the reader's familiarity with the subject matter, among other factors.

The choice of teaching learning strategy must be formulated by the teacher in getting the teaching goals that have been formulated. Abbot and Peter (1985) state that it is necessary to choose appropriate teaching techniques so that our learners read efficiently the material presented to them. The strategy can give chance to the students to open their insight, to express opinion and to appreciate friends' opinion.

We know that the techniques of teaching reading that most teachers used are reading aloud, skimming, scanning, answering questions related to the material, without explanation how to help the students understand the material. Most books on science and technology are written in English. Reading is an important activity to get the knowledge and information of the world. Therefore, we must have adequate English knowledge to understand what we read. Based on this matter, the writer will try to analyze words, phrase, sentence, and paragraph in English teaching process on understanding the material that the students read. There are five skills to analyze word to paragraph to improve comprehension in reading, namely: (1) deducing the meanings of words from the contexts, (2) understanding the forms and meanings of non-idiomatic phrase, (3) understanding sentence meaning through syntactical structures, (4) recognizing and understanding rhetorical structures, and (5) critical reading skills.

Since the focuses of the research are the use of word to paragraph analysis toward students reading' reading comprehension, the problems of the research are: (1) Does the use of word analysis improve the students' reading comprehension? (2) Does the use of phrase analysis improve the students' reading comprehension? (3) Does the use of 
sentence analysis improve the students' reading comprehension? (4) Does the use of paragraph analysis improve the students' reading comprehension?

The finding of this research is expected to be useful for the improvement of students' reading comprehension and become the alternative method for teacher in teaching reading.

Since the emphasis of reading comprehension is reading aloud, skimming, scanning, and answering the questions, this research is restricted to use word to paragraph analysis on students' reading comprehension. The concepts that are related to the research focus on the use of word to paragraph analysis toward students' comprehension in teaching reading.

Reading is defined as an active attempt to understand a writer's message. The readers interact with, and try to reconstruct, what a writer wishes to communicate (Smith and Alan, 1980). Simanjuntak (1988) defines reading as the process of putting the reader in contact and communication with ideas. Another definition of reading stated by William (1991) that reading is a process whereby one looks at and understands what has been written. The key word here is 'understand' - merely reading aloud without understanding does not count as reading. Asking students to read aloud, if a teacher already knows that they can read, is an activity of very limited value.

Byrnes (2004) says that reading is an interactive process that goes on between the reader and the text, resulting in comprehension. The text presents letters, words, sentences, and paragraphs that encode meaning. The reader uses knowledge, skills, and strategies to determine what that meaning is. Reader's knowledge, skills, and strategies include: (1) Linguistic competence: the ability to recognize the elements of the writing system; knowledge of vocabulary; knowledge of how words are structured into sentences, (2) discourse competence: knowledge of discourse markers and how they connect parts of the text to one another, (3) sociolinguistic competence: knowledge about different types of texts and their usual structure and content, and (4) strategic competence: the ability to use top-down strategies, as well as knowledge of the language (a bottom-up strategy).

To analyze word to paragraph in improving students' reading comprehension, the students need to know some types of reading skills. Nation (1988) gives reading skills that are commonly practiced 
in language learning. They are as the ability to: (1) have the knowledge. of word forms and their meanings. To read successfully a student should be able to recognize words and recall their meanings quickly, (2) see the meaning of a known word in a particular context. The meaning of a word changes according to the other words and the sentences around it. Students need to be able to see the particular meaning of a word in a particular context, (3) guess the meaning of unknown words by seeing them in context. This skill is extremely important for reading as it is important way of learning new vocabulary, (4) avoid paying attention to unknown words that are not essential to the understanding of a passage. Often unknown words do not add any essential meaning to a passage and if the reader gave attention to them, they could interrupt the flow of reading, (5) have the knowledge of the main sentence pattern. This is usually not very different to learn because the knowledge needed to be able to read is for less the knowledge of the sentence pattern needed for reading, (6) follow the organization of a reading passage or book, (7) see the main though of the writer and get the general idea of a piece of reading, (8) get the meaning from a piece of writing. This skill is often called of study reading, (9) understand and find certain details, either words or ideas, in piece of reading. This includes the ability to see how the meaning of a sentence has an affect on and is affected by other sentences, (10) be critical of what is being read. This included seeing the techniques that a write uses to show his ideas, (11) read between the units, that is to understand the ideas that are not directly mentioned in the passage to see the feeling and opinions of the writer, (12) read quickly with good understanding, and the ability to skim, (13) suit reading speed to the nature of the material. This includes the ability to change the reading speed according to the nature of the material, and (14) guess what words, phrases, or larger parts of a piece of reading will follow given sentence.

Furthermore, one possible way of establishing a purpose for reading is by focusing the learners' attention on a particular cognitive skill. Abbot and Peter (1985) give cognitive skills of comprehension as the ability to: (1) anticipate both the form and the content, (2) identify the main ides(s), (3) recognize and recall specific details, (4) recognize the relationship between the main idea(s) and their expansion (example, etc), (5) follow a sequence, e.g. events, instructions, stages 
of an argument, (6) infer from the text (read between the lines), and (7) recognize the writer's purpose and attitude.

Moreover, Heaton (1975) says that the specific skills in reading can be defined as the ability to: (1) recognize words and word groups, associating sounds with their corresponding graphic symbols, (2) deduce the meaning of words by understanding words formation (roots, affixation, derivation and compounding) and contextual clues (e.g. One of the members of the group exposed the plot, and the polices wete soon able to arrest the leaders.), (3) Understand explicitly stated information (e.g. I wish Ann had come = Ann did not come hence my wish.), (4) understand relations within the sentence, for instances: elements of sentence structure, negation, fronting and theme, and complex embedding, (5) understanding relations between parts of a text through both lexical devices (e.g. repetition, synonyms, antithesis) and grammatical cohesive devices, especially anaphoric and cataphoric reference (e.g. he, they, it; the, former, the letter) and connectives (e.g. since, after, because, although, however, in addition), (6) perceive temporal and spatial relationships, and also sequences of ideas, (7) understand conceptual meaning, especially: quantity and amount, definiteness and indefiniteness, comparison and degree, means and instrument, and cause, result, purpose, reason, condition, addition, contrast, concession, (8) anticipate and predict what will come next in the text, (9) identify the main idea and other salient features in a text, (10) generalize and draw conclusions, (11) understand information not explicitly stated by: making inferences (i.e. reading between the lines) and understanding figurative language, (12) skim and scan (looking for the general meaning and reading for specific information), (13) read critically, and (14) adopt a flexible approach and vary reading strategies according to the type of material being read and the purpose for which it is being tead.

To improve comprehension in reading based on word to paragraph analysis above, the writer classifies of five skills to analyze word to paragraph, namely: (1) deducing the meanings of words from contexts, (2) understanding the forms and meanings of non-idiomatic phrase, (3) understanding sentence meaning through syntactical structures, (4) recognizing and understanding thetorical structures, and (5) critical reading skills. 
Reading comprehension can be improved by deducing the meanings of words from context. Deducing the meanings of words from context can be looked before or after the words or phrases in the sentence in order that they can be known the functions and word types

Meanwhile, students' reading comprehension can also be improved by understanding the forms and meanings of non-idiomatic phrase. Phrases idiomatic posse's forms and meaning constantly, so they should be memorized to understand a sentence and even paragraph. They differs with non-idiomatic phrases are formed that base on noun phrase, gerund phrase, participial phrase, predicative verb phrase, and infinitive phrase.

Moreover, students' reading comprehension can also be improved by understanding sentence meaning through syntactical structures. This skill is the application of grammar knowledge especially syntax to identify word, phrase or sub-clause in the main sentence (Subject, Predicate, Object, Adverb or complement).

Furthermore, recognizing and understanding rhetorical structures can also improve reading comprehension. Rhetorical structure is the relationship of the meaning functions in a paragraph or text in reading. Structure is a basic concept of the text and relationship between the topic, writer's goal, and readers.

Recognizing and understanding of the rhetoric structure understands the meanings and the functions of word, phrase, punctuation, and the structures which are used by writer to give and to describe his idea or massage to readers.

The rhetoric structure can be found at sentence level. It can be found by: (1) understanding the meaning of word or conjunction (contrast, causal, condition, emphasize).

The rhetoric structure can also be found at paragraph level. It can be found by: (1) understanding the meaning of word or conjunction, (2) understanding topic and main idea, and (3) understanding the relationship of main idea and support sentence.

The rhetoric structure can also be found in the text level. It can be found by: (1) understanding theme and central idea, (2) understanding the functions of each paragraph, and (3) understanding of parts and functions of each part in a text.

In addition, critical reading skill is one of five skills to comprehend in reading material. It can be done by understanding the writer's meant 
related to: (1) purpose, (2) perspectives (reality, inference, or writer's idea), (3) language and critical of writing format.

\section{B. Research Methode}

The design of this research method to be applied in this research consists of two groups (experiment group and control group) which were formed randomly. Both groups were given pretest and posttest. The pretest is administered to find out the students' prior knowledge while the posttest is used to find out achievement of the students after receiving treatment (the analysis of word to paragraph technique). One group received unusual treatment (teaching reading by using word to paragraph analysis), and the other group received the usual treatment (teaching reading by using conventional technique). Meanwhile, word to paragraph test was given when the treatments were implemented. There four kinds of word to paragraph test, namely: (1) word test, (2) phrase test, (3) sentence test, and (4) paragraph test.

The analysis of word to paragraph technique is the instruction of reading material in order that students understand what the writer meant in his written. Word to paragraph analysis means that the students understand and identify: (1) the kinds of words and their function (e. q. noun, verb, pronoun, adjective, adverb, preposition, conjunctions), (2) words related to: root, prefix, suffix, their function in sentence, the closed auxiliary words, and the meanings of words from reading context, (3) the kinds of phrases and their meanings from the context, (4) the simple sentence, compound sentence, complex sentence, and compound complex sentence, and (5) the relationship between sentence and sentence by using conjunction, main sentence and support sentence, and topic, main idea, and support sentence. Meanwhile, the students' comprehension is the students' actual ability on reading by using word to paragraph analysis.

Population of this research is the second semester students of English Department of Tarbiyah Faculty of UIN Alauddin Makassar. They consist of four groups formulated 75 students. The researcher takes two groups as sample. Each group consists of 19 students. The students are chosen by using sample random activities. So there are 38 students taken as sample in this research.

The instrument of the research is six tests consist two tests are given before and after giving the treatment, namely pre-test and post- 
test and four test of word to paragraph analysis were given when the treatments were implemented. Two tests mean that before giving the treatment, in the first test, the students will be asked to read the material and to ask some questions based on the topic given. This test is given in order to get data on the students' prior knowledge. In the second test, post-test, the students are asked to read the other material and given some questions which related to material. This activity is intended to find out the students' comprehension in reading after they are given the treatment.

The data was collected by using the procedure: (1) pretest, (2) treatment, and (3) posttest. The first procedure focused on pretest. Before doing the treatment, the students were given pretest to know their prior knowledge. In this case, the writer gave a topic of reading material and asked the students to read and to answer some questions related to the material. The second procedure focused on the treatments. Teacher explained how to improve students' reading comprehension by using word to paragraph analysis. It was taught and divided into 4 steps, namely: (1) using word analysis, (2) using phrase analysis, (3) using sentence analysis, and (4) using paragraph analysis.

Teacher provided sixteen topics of reading materials relating to: education, economics, Islamic studies, science, etc. They were distributed to the students for twelve meetings and four topics for homework. The topic material was that the students were asked to read and to analyze using word to paragraph by pairing and individual. They were also asked to answer some questions for each topic and given four tests in each steps for collecting data score. Word to paragraph analysis was taught by using of four steps: (1) word analysis, (2) phrase analysis, (3) sentence analysis, and (4) paragraph analysis.

The first step focuses on word analysis. This step consists of three meetings which were analyzing words and answering questions. The flow of teaching reading by using word analysis is as follows: (1) teacher gives the students some questions as warming up, (2) students classify the kinds of words relating to: noun, verb, adjective, adverb, preposition, conjunction, pronoun, auxiliary verb, auxiliary of noun, and auxiliary of adjective, (3). students identify the words from the text relating to: roots, prefix, and suffix, the functions of word in sentence, the closed auxiliary words (e.g. a, the, some, many, in, on for, always, never, often, will, can, very, rather, fairly, quite, so), and 
the meanings from the reading text (e.g. synonym, antonym, causeeffect relationships, hyponymy, explanation, examples, comprehending the whole text, reference), (4) Students answer the questions from the text to find the specific information, (5) students complete the sentence, (6) teacher gives the students opportunity to express their difficulties faced in the class, (7) teacher explains what the students have analyzed that related the words, (8) teacher gives the students homework as follow up, and (9) teacher gives the test to measure the students' mastery of word.

Second step focuses on phrase analysis. This step consists of three meetings which were analyzing phrases and answering questions. The flow of teaching reading by using phrase analysis as follows: (1) teacher gives the students some questions as warming up, (2) students identify the kinds of phrases to complete the table, (3) students find the meanings of the kind of phrase, (4) students identify a group of nouns and find its meanings from the context, (5) students answer the questions from the text to find the specific information, (6) students complete the sentence, (7) teacher gives the students opportunity to express their difficulties faced in the class, (8) teacher explains what the students have analyzed that related the phrases, (9) teacher gives the students homework as follow up, and (10) teacher gives the test to measure the students' comprehension on phrases.

Third step focuses on sentence analysis. This step consists of three meetings which were analyzing sentence and answering questions. The flow of teaching reading by using sentence analysis as follows: (1) teacher gives the students some questions as warming up, (2) students identify simple sentence, (3) students identify compound sentence, (4) students identify complex sentence, (5) students identify compound complex sentence, (6) students find the meanings of the kinds of sentences, (7) students answer the questions from the text to find the specific information, (8) teacher gives the students opportunity to express their difficulties faced in the class, (9) teacher explains what the students have analyzed that related to the sentence, $(10)$ teacher gives the students homework as follow up, and (11) teacher gives the students test to measure the students' sentence on reading comprehension.

The fourth step focuses on paragraph analysis. This step consists of three meetings which were analyzing paragraph and answering questions. The flow of teaching reading by using paragraph analysis as 
follows: (1) teacher gives the students some questions as warming up, (2) students identify the relationship between sentence and sentence by using conjunction, (3) students identify main sentence and support sentence, (4) students identify topic and main idea, (5) students answer the questions from the text to find the specific information, (6) teacher gives the students opportunity to express their difficulties faced in the class, (7) teacher explains what the students have analyzed that related the paragraph, (8) teacher gives the students homework as follow up, and (9) teacher gives the students test to measure the students' paragraph on comprehension reading.

The students were also asked to analyze word, phrase, sentence and paragraph by individually at home (homework). After doing the treatment, students were asked to read new topic and answer the questions (posttest).

After the students were given treatment, the posttest was conducted to find out the student's achievement. The writer provided new topic and some questions related to topic. This test was intended to know whether or not that word to paragraph analysis can improve the students' reading comprehension.

The data were collected in line with instruments and analyzed using the procedures: (1) scoring the result of the students' test, (2) tabulating the score of the students, (3) classifying the score of the students, (4) calculating the mean score, (5) calculating the standard deviation, (6) calculating the value of correlation, and (7) calculating the value of multiple regressions.

\section{Findings and Discussion}

Reporting the result of research was divided into two parts in the findings and discussion, namely: (1) Students' achievement of pretest and posttest and (2) Students' achievement of word to paragraph and reading comprehension test.

\section{Students' achievement of pretest and posttest}

The following table is the description result of the students' pretest and post-test score. The calculation of the mean score and standard deviation are done to know whether or not the difference between the students' reading comprehension score in experimental group and the students' reading comprehension score in control group. 
1) The mean score and standard deviation of students' pre-test and post-test

Table 1. The students' reading comprehension achievement improvement

\begin{tabular}{lllccc}
\hline & \multicolumn{2}{c}{ Pre-test } & \multicolumn{2}{c}{ Post-test } \\
\cline { 3 - 6 } & & Control & Experimental & Control & Experimental \\
\hline Respondents & $:$ & 17 & 18 & 16 & 19 \\
Mean & $:$ & 61.82 & 61.67 & 63.63 & 74.74 \\
SD & $:$ & 12.71 & 11.75 & 8.04 & 13.89 \\
\hline
\end{tabular}

Sowre: survey, 2006

From the table above we may conclude that the mean score of experimental group is different toward control group.

Based on the data shown in the pre-test score, it can be concluded that there is not difference between the students' score in experimental group and the students' score in control group. It can be proved that the mean score of experimental group is 61.67 and the control group is 61.82. It is supported the standard deviation score of experimental group is 11.75 and the control group is 12.71 . It means that the students' achievement of both the groups in reading comprehension is almost the same before they are given treatments. The researcher concludes that the students' prior knowledge has relatively the same.

Furthermore, the data also shown on the table of post-test score that is different with the pre-test score, the researcher concludes there is significant difference between the students' score in experimental group and the students' score in control group. It can be stated that the students' mean score of experimental group is 74.74 but the control group is 63.63 , while the standard deviation of experimental group is 13.89 and the control group is 8.04. It means that the students' comprehension both the groups in reading are significant difference after they are given treatments.

Related to the explanation above, it can be concluded that the students' comprehension in pre-test, there is no different between the experiment group and control group before giving the treatments. However, after they are given the treatments, the students' comprehension improved in reading material. 
2) The t-test value of the students' pre-test and post-test

Table 2. The t-test value of the students' pre-test and post-test

\begin{tabular}{ccccc}
\hline No. & Test & T-observation & t-table & Probability \\
\hline 1 & Pre-test & 0.038 & 2.042 & 0.97 \\
2 & Post-test & 2.822 & 2.042 & 0.008 \\
\hline
\end{tabular}

Source: survey, 2006

In pre-test part above shown that t-observation $(0.038)<\mathrm{t}$-table (2.042), at 0.05 levels of significant and at 33 degrees of freedom indicates that $\mathrm{H}_{0}$ is accepted, so the data is no significant. It means that the students' mean score between experimental group and control group was relatively the same. Thus, the experimental group and the control group have the same or relatively the same of baseline knowledge before the treatment.

Moreover, in post-test part above also informed us that probability $(0.008)<\mathrm{t}$-table $(0.05)$ and the $\mathrm{t}$ - observation was higher than $\mathrm{t}$-table, where t-observation (2.822) > t-table (2.042), at 0.05 levels of significant (á) and at 33 degrees of freedom (df). This data indicates that the statistical hypothesis of $\mathrm{H}_{\mathrm{o}}$ was rejected and of course, the statistical hypothesis of $\mathrm{H}_{1}$ was acceptable. It means that the students' comprehension in reading by using word to paragraph analysis was able to give significant contribution than the students' comprehension in reading with conventional teaching. It can be stated that the use of word to paragraph analysis could improve the students' reading comprehension.

2. Students' achievement of word to paragraph and reading comprehension test

Table 3. The correlation between word to paragraph analysis and reading comprehension

\begin{tabular}{llccc}
\hline No. & Variables & Correlation $\left(\mathrm{R}^{2}\right)$ & Percentage $(\%)$ & Probability \\
\hline 1. & Word & 0,64 & 64 & 0,003 \\
2. & Phrase & 0,10 & 10 & 0,693 \\
3. & Sentence & 0,69 & 69 & 0,001 \\
4. & Paragraph & 0,51 & 51 & 0,025 \\
\hline
\end{tabular}


The table above shown us that the most of variables contributed to students' comprehension in reading except phrase variable, but the students' score of contributions are different. Based on the table above shown that sentence analysis score is 68 percent. It is the highest variable of correlation which has positive correlation between sentence analysis and reading comprehension. This means that $69 \%$ of students' reading comprehension is contributed by sentence analysis. it can also be seen at level of significant that It has a significant correlation where its probability is lower than $\mathrm{r}$ - table $(0.001<0.433)$, the next variable analysis is followed by word analysis. The percentage of word analysis is 64 percent. It has also positive correlation between word analysis and reading comprehension. It means that $64 \%$ of reading comprehension is contributed by word analysis. It is supported by probability which is lower than $r$-table $(0.003<0.433)$ at level of significant $(5 \%)$. This means that there is a significant correlation between word analysis and reading comprehension. In addition, paragraph analysis has also positive and significant correlation between paragraph analysis and reading comprehension. It can be seen on table that its probability is lower than r-table $(0.025<0.433)$ and the percentage of paragraph analysis is 51 percent. It means that 51 percent of reading comprehension is contributed by paragraph analysis. However, phrase analysis is the lowest variable of correlation which has not positive correlation between phrase analysis and reading comprehension. The percentage of phrase analysis is 10 percent and its probability is higher than $\mathrm{r}$-table. It means that only $10 \%$ of reading comprehension is contributed by phrase analysis.

Table 4. The contribution of word to paragraph analysis on reading comprehension

\begin{tabular}{lcccc}
\hline Variables & R Square & $\%$ & F Value & Probability \\
\hline $\begin{array}{l}\text { (Word, Phrase, } \\
\text { Sentence, Paragraph) }\end{array}$ & 0.62 & 62 & 5,695 & 0,006 \\
\hline
\end{tabular}

Source: survey, 2006 
Based the table above shown that there is a positive correlation between word to paragraph analysis and students' reading comprehension. It can be seen the second column that R Square (R2) score is 0.62 . The percentage of $\mathrm{R}$ Square is 62 percent. It means $62 \%$ of students' reading comprehension is contributed by word to paragraph analysis.

The findings above are clearly shown by the students' mean score between the result of pre-test and pos-test. In this case the mean score of pre-test is 61.82 for control group and 61.67 for experimental group. This means that the students who obtained the students' prior knowledge are relatively the same. After they are given the treatments, the comparison between experimental groups is better than control group. This means the students' score increase after the students are given treatment such 63.63 for control group and 74.74 for experimental group.

The researcher also observes that after the students are given treatments, there is a significant difference between the mean score in experimental group and control group. The proof of it can be seen from the result of the t-test analysis. The researcher find out that the $\mathbf{t}$-observation value of post test (2.822) is higher than t-table (2.042), at the level of significance 0.05 of the degree of freedom (df) 33 . It means that the students' reading comprehension could be improved by using word to paragraph after they are given the treatments.

Beside giving the pre-test and post-test, during conducting the treatments, the researcher has also given the four times of test for four variables, namely: word analysis, phrase analysis, sentence analysis and paragraph analysis. This is intended to measure how fat the correlation and contribution of each variable on students' comprehension in reading. The following discussions are divided into four discussions of result of the use of: (1) word analysis, (2) phrase analysis, (3) sentence analysis, and (4) paragraph analysis.

The first discussion section focuses on word analysis. To improve reading comprehension, Nation (1988) says that students should be able to recognize words and recall their meaning quickly; students need to be able to see the particular meaning of a word in a particular context, and the ability to guess the meaning of unknown words by seeing them in context. McWhorter (1992) adds that many words in the English language are made up of words parts called prefix, root, and suffix. 
Based on the findings above showed that word analysis has positive correlation on students' reading comprehension. It can be seen the students' achievement that 64percent of students' reading comprehension is contributed by word analysis. It can also be stated that there is a significant correlation between word analysis and reading comprehension. The proof of data shown that probability value is lower than $\mathrm{t}$ - table $(0.003<0.433)$, at level of significant $(5 \%)$. It supports the theory that to improve reading comprehension, students have ability to recognize forms words and their meanings and to identify the kinds of words. Thus, word analysis could improve the students' comprehension in reading.

Second discussion focuses on phrase analysis in this section, the researcher observes that the students found difficult to study phrase. It is proved that its probability $(0.693)$ is higher than r-table $(0.433)$. This means there is no significant correlation between phrase analysis and reading comprehension. In addition, it is proved by the contribution of phrase to reading comprehension is only 10 percent. It indicates that the rate percentage of students is the least of contribution of students' phrase towards reading comprehension. In this case, it indicates that students lack knowledge to identify the difference between a group words which has not complete meaning and a group of words which has meaning sense. They also lack knowledge to identify the meaning of phrasal verb. Therefore, phrase analysis is not able to improve students' comprehension in reading.

Sentence analysis is third discussion that has positive correlation on reading comprehension. The rate percentage of sentence analysis score indicated that 69 percent of students' reading comprehension contributed by sentence analysis. Sentence analysis is the highest variable to contribute toward reading comprehension. Furthermore, sentence analysis is also significant correlation on students' reading comprehension. It can be proved by probability value which is lower than $\mathrm{r}$-table $(0.001<0.433)$.

Nation (1988) says that knowledge of the main sentence pattern is one of reading skills. Heaton (1975) adds that students must have ability to understand relations within the sentence and understanding explicitiy stated information. These theories are proved by students with the analysis of sentence. They can distinguish between phrase and sentence. They can also identify the kinds of sentence, main 
sentence, coordinate clause and subordinate clause. Thereby, the researcher concludes that sentence analysis could improve students' comprehension in reading material.

Paragraph analysis is one of four variables that used to improve students' reading comprehension. Nation (1988) says that to comprehend in reading, students should have the ability to the main though of the writer and get the general idea of a piece of reading, and the ability to be critical of what is being read. Heaton (1975) adds that students must have the ability to understand information not explicitly stated by making inferences (i.e. reading between the lines), understand conceptual meaning, especially: (1) quantity and amount, (2) definiteness and indefiniteness, (3) comparison and degree, (means and instrument), and (5) cause, result, purpose, reason, condition, addition, contrast, concession.

Based on the score in the data finding, the researcher concludes that the use of paragraph analysis could improve students' reading comprehension. It can be seen that paragraph analysis has significant correlation on reading comprehension. In this case, 51percent of reading comprehension is contributed by paragraph analysis. It is also supported by the probability which is lower than $\mathrm{r}$ - table $(0.025$ $<0.433$ ). In relating to the experts toward this finding indicates that students have ability to understand main idea in a paragraph, identify the relationship between sentence and sentence by using conjunction such as cause, result, purpose, reason, condition, addition, and contrast. Thus, it can be concluded that the use of paragraph could improve students' reading comprehension.

Based on some previous explanation above, teaching reading by using word to paragraph analysis could improve the students' reading comprehension. In this case, there is significant correlation between the use of word to paragraph analysis and students' reading comprehension, where its probability $(0.006)$ is lower than r-table $(0.349)$. It is also proved by the score of assumption that 62 percent of word to paragraph analysis could improve students' reading comprehension.

Based on the interpretation above, the use of word to paragraph can be explained that students could identify the kinds and the forms of word and the types of sentence. They could also know the meaning of word and sentence. However, number of students is lack to know the difference between a group of words which has not 
completely meaning (phrase) and has completely meaning (sentence) and they were also lack to know the meaning of phrasal verbs. Thereby, researcher concludes that the sixty two percent of word to paragraph analysis contributed to improve students' reading comprehension.

\section{E. Conclusion and Suggestion}

Based on the description discussed above, the researcher concluded that the use of word, sentence, and paragraph analysis could improve the students' reading comprehension, but phrase analysis could not improve students' comprehension in reading.

After the students are given the treatments, although one of variable does not have significant correlate with reading comprehension, it can be concluded that word to paragraph analysis could improve students' reading comprehension. It could be proved that 62 percents of word to paragraph analysis contributed to students' reading comprehension. Because the assumption of percentage shown that word to paragraph analysis has positive correlate with students' reading comprehension. It is supported by the significant correlation between word to paragraph analysis and students' reading comprehension.

Related to the subject (reading comprehension) discussed above and in order to improve the teaching of reading comprehension to the students, the suggestion goes to: (1) since the students' achievement taught reading comprehension by using word to paragraph analysis is increasing significantly, the researcher expects to the teacher of English to apply the technique in teaching reading comprehension and (2) it is recommended that the readers of this thesis use the technique (word to paragraph analysis) in order to improve the students' achievement and to carry out a deepen investigation to examine whether or not the use of word to paragraph analysis can improve the students' comprehension in reading material.

\section{REFERENCES}

Abbot, Gerry and Peter Wingard. 1985. The Teaching of English as An International I anguage. A Practical Guide. London: Biddle Ltd, Guildford, Survey.

Anonymous. (1997). "Comprehension". Readingrocketr. Online: http://www. readingrockets.org/helping/target/comprehension. Diakses Jan 10, 2006 
Byrnes, Heidi. 2004. Reading in the beginning and intermediate college foreign language class. Online http://www.nclc.otg/essentials/ reading.htm. Jan 10, 2006.

Heaton, J.B. 1975. Writing English Language Test. New Edition Longman Group. New York.

Nation, Paul. 1988. Communication Activities. New Zealand: Victoria University of Wellington Press.

Nuttal, Christine. 1982. Teaching Reading Skills in A Foreign Langunge. London: Heinemann International.

Simanjuntak, Edithia Gloria. 1988. Developing Reading Skill for English Foreign Language Students. Jakarta: Depdikbud.

Smith, B Nila and H.A. Alan Robinson. 1980. Reading Instrution For today's Students:London: Prentice--Hall Inc Engleword Cliffs.

William, Edie. 1991. Reading In The Language Classroom. London: Modern English publication

Wiriyachitra, Arunee and Chanya Apichattrakul. 1989. How to Read Scientific and Technical English Understandably. Washington: A Forum Anthology Volume IV. 